\title{
Gambaran Interaksi Caring Perawat dengan Pasien: Studi Pendahuluan
}

\author{
Dina Ayu Mentari' ${ }^{1}$, Sarah Ulliya ${ }^{2}$ \\ 1,2 Departemen Ilmu Keperawatan Fakultas Kedokteran, Universitas Diponegoro, Semarang, Indonesia \\ s.ulliya024@gmail.com
}

\begin{abstract}
Introduction: In nursing practice nurses often show less optimal caring interactions because they have overload tasks. The purpose of this study was to describe the caring interactions between nurses and patients.

Methods: This study was a descriptive study with a survey approach. The samples were 89 nurses at the inpatient wards who were recruited using purposive sampling technique. The data were collected using the Caring Nurse-Patient Interactions (CNPI-23N) tool and analyzed using a univariate analysis presented in the form of the frequency distribution.

Results: The results showed that $84.3 \%$ of caring interactions between nurses and patients were good, and the remaining $18.7 \%$ were adequate. The dimension of comforting care achieved the highest value in which all respondents (100\%) were at a good level. Meanwhile, the dimension of humanistic care achieved the lowest value in which $38.2 \%$ of respondents were at an adequate level.

Conclusion: This study concluded that the caring interactions between nurses and patients had been well implemented. It is expected that the nursing profession and the hospital management maintain the quality of nursing care and increase the knowledge and training.
\end{abstract}

Keywords: Caring Interaction, Patient, Nurse.

\begin{abstract}
Abstrak
Pendahuluan: Perawat sering menunjukkan interaksi caring yang kurang optimal karena disibukkan dengan tugas yang harus diselesaikan. Tujuan penelitian ini untuk mendeskripsikan gambaran interaksi caring perawat dengan pasien.

Metode: Penelitian ini adalah studi deskriptif dengan pendekatan survei. Teknik sampling yang digunakan adalah purposive sampling, jumlah sampel sebanyak 89 ners di ruang rawat inap rumah sakit. Penelitian ini menggunakan instrumen Caring Nurse-Patient Interactions (CNPI-23N) tools. Analisa data menggunakan analisis univariat yang disajikan dalam bentuk distribusi frekuensi.

Hasil: Hasil penelitian menunjukkan bahwa interaksi caring perawat dengan pasien di ruang rawat inap rumah sakit sebesar 84,3\% dalam kategori baik dan sebesar 18,7\% dalam kategori cukup. Dimensi comforting care merupakan dimensi dengan nilai tertinggi sebesar $100 \%$ responden dalam kategori baik, sedangkan dimensi humanistic care merupakan dimensi dengan nilai terendah sebesar 38,2\% responden dalam kategori cukup.

Kesimpulan: Kesimpulan dari penelitian ini, interaksi caring perawat dengan pasien sudah diterapkan dengan baik. Profesi keperawatan dan pihak rumah sakit diharapkan dapat mempertahankan kualitas atau mutu pelayanan asuhan keperawatan serta meningkatkan pengetahuan dan pelatihan.
\end{abstract}

Kata kunci: Interaksi caring, Pasien, Perawat. 


\section{PENDAHULUAN}

Keperawatan merupakan profesi yang unik karena praktik keperawatan difokuskan pada respon individu terhadap masalah kesehatan yang dialaminya. Salah satu bentuk keperawatan yang profesional adalah caring perawat dalam memberikan asuhan keperawatan yang menjadi inti dari pemberian asuhan keperawatan pada pasien (Potter \& Perry, 2009). Caring perawat dapat terwujud dalam interaksi perawat dengan pasien. Kekuatan interaksi langsung yang ditunjukkan oleh perawat memiliki peran yang besar dan berpengaruh dalam proses penyembuhan pasien. Interaksi caring perawat dengan pasien mencakup segala sikap dan perilaku perawat dalam ranah praktik humanistik, relasional, dan praktik keperawatan klinis (Cossette, Cote, Pepin, Ricard, \& D'Aoust, 2006).

Penelitian yang dilakukan rumah sakit di Lampung menunjukkan bahwa perilaku caring perawat mempengaruhi kepuasan pasien Penelitian tersebut menyatakan bahwa mayoritas perilaku caring perawat rendah yaitu sebanyak $56,3 \%$ dari 54 responden (Tiara \& Lestari, 2013). Penelitian lain di sebuah rumah sakit di Semarang menunjukkan hasil bahwa persepsi pasien terhadap caring perawat kurang yaitu sebesar 55,8\% sehingga pelayanan keperawatan dianggap kurang memuaskan (Sukesi, 2012). Sebuah penelitian yang dilakukan di rumah sakit Filipina tentang komponen interaksi caring perawat menunjukkan bahwa faktor humanisme menjadi faktor yang paling diterapkan dalam interaksi caring perawat dengan pasien (Fortuno, Oco, \& Clores 2017).

Seorang perawat sering menunjukkan interaksi caring yang kurang optimal dalam praktik keperawatan karena disibukkan dengan tugas yang harus diselesaikan. Perawat yang bekerja dirawat inap rata-rata memiliki beban kerja yang berat. Tugas yang harus dilakukan perawat antara lain menyiapkan dan melakukan pemberian obat kepada pasien, melakukan komunikasi dengan pasien, mengukur dan mengobservasi tanda-tanda vital pasien, melakukan obervasi dan pemasangan infus, perawatan luka, melakukan pemasangan dan mengontrol kebutuhan oksigen pada pasien (Jannah, Rizani, \& Marwansyah, 2016).

Hasil studi pendahuluan menunjukkan bahwa perawat menyebutkan jarang berinteraksi dengan pasien, interaksi dilakukan ketika timbang terima dan saat memberikan tindakan berdasarkan wawancara yang dilakukan, menunjukkan bahwa pengetahuan perawat tentang clinical care adalah rutinitas pekerjaan sebagai perawat. Perawat mewujudkan relational care dengan cara komunikasi dengan pasien. Perawat menganggap pasien sebagai individu yang harus dihormati, ditolong dan dimotivasi pada humanistic care dan memperhatikan kenyamanan lingkungan pasien pada comforting care.

Penelitian terdahulu menjelaskan tentang persepsi perawat terhadap interaksi caring perawat Filipina dengan pasien. Faktor humanistic care menjadi faktor yang sering diterapkan dalam interaksi perawat dengan pasien dari keempat komponen interaksi caring (Fortuno, Oco, \& Clores 2017). Penelitian tentang interaksi caring perawat dalam empat faktor di Indonesia belum diteliti, dan tujuan penelitian ini adalah mengidentifikasi empat komponen interaksi caring perawat dan pasien. 


\section{METODE}

Jenis penelitian ini adalah deskriptif survei dengan tujuan untuk mendeskripsikan gambaran interaksi caring perawat dengan pasien. Metode survei dalam penelitian ini dilakukan dengan menggunakan pengisian kuesioner. Populasi dalam penelitian ini adalah perawat ruang rawat inap sejumlah 107 perawat. Teknik sampling yang digunakan adalah purposive sampling, jumlah sampel sebanyak 89 responden. Kriteria inklusi dalam penelitian ini adalah perawat ruang rawat inap bangsal dewasa dan bersedia menjadi responden dengan menandatangani lembar persetujuan (informed consent). Variabel yang digunakan dalam penelitian ini adalah interaksi caring perawat dengan pasien. Alat penelitian dalam penelitian ini adalah kuesioner Caring Nurse-Patient Interaction (CNPI-23N). Uji validitas kuesioner dengan menggunakan back translation method dan analisis data menggunakan analisis univariat. Pengambilan data dilakukan pada 22 Oktober 9 November 2018 di ruang rawat inap rumah sakit. Penelitian ini disetujui oleh Komisi Etik Penelitian Kesehatan Rumah Sakit Umum Daerah Tugurejo Semarang dengan No. 94/KEPK/X/2018.

\section{HASIL}

1. Distribusi Frekuensi Karakteristik Responden

\begin{tabular}{lll}
\hline Karakteristik Responden & f & \% \\
\hline Usia & & \\
Remaja akhir (17-25 tahun) & 4 & 4,5 \\
Dewasa awal (26-35 tahun) & 53 & 59,6 \\
Dewasa akhir (36-45tahun ) & 31 & 34,8 \\
Lansia awal (46-55 tahun) & 1 & 1,1 \\
Jenis Kelamin & & \\
Laki-laki & 32 & 36 \\
Perempuan & 57 & 64 \\
Masa Kerja & & \\
1-5 tahun & 47 & 52,8 \\
>5 tahun & 42 & 47,2 \\
Jenjang Karir & & \\
PK I & 49 & 55,1 \\
\hline
\end{tabular}

\begin{tabular}{lll}
\hline Karakteristik Responden & f & \% \\
\hline Jenjang Karir & 17 & 19,1 \\
PK II & 22 & 24,7 \\
PK III & 1 & 1,1 \\
PK IV & & \\
Status Kepegawaian & 41 & 46,1 \\
PNS & 48 & 53,9 \\
Non-PNS & & \\
Status Pernikahan & 81 & 91 \\
Menikah & 8 & 9 \\
Belum menikah & & \\
\hline
\end{tabular}

\section{Distribusi Frekuensi Interaksi Caring Perawat dengan Pasien $(\mathbf{n}=89)$}

\begin{tabular}{lll}
\hline Interaksi Caring & f & \% \\
\hline Baik & 75 & 84,3 \\
Cukup & 14 & 15,7 \\
Rendah & 0 & 0 \\
\hline Total & 89 & 100 \\
\hline
\end{tabular}

\section{Distribusi Frekuensi Empat Dimensi Interaksi Caring Perawat dengan Pasien $(\mathbf{n}=89)$}

\begin{tabular}{llcccccc}
\hline \multirow{2}{*}{ No } & \multirow{2}{*}{ Dimensi } & \multicolumn{2}{c}{ Baik } & \multicolumn{2}{c}{ Cukup } & \multicolumn{2}{c}{ Renda } \\
& & f & \% & f & \% & f & \% \\
\hline 1 & Clinical care & 88 & 98,9 & 1 & 1,1 & 0 & 0 \\
2 & Relational care & 63 & 70,8 & 26 & 29,2 & 0 & 0 \\
3 & $\begin{array}{l}\text { Humanistic } \\
\text { care }\end{array}$ & 55 & 61,8 & 34 & 38,2 & 0 & 0 \\
4 & $\begin{array}{l}\text { Comforting } \\
\text { care }\end{array}$ & 89 & 100 & 0 & 0 & 0 & 0 \\
& & & & & & \\
\hline
\end{tabular}

\section{PEMBAHASAN}

Hasil penelitian menunjukkan interaksi caring perawat dengan pasien di ruang rawat inap rumah sakit dalam kategori baik sebesar $84,3 \%$. Perawat menilai caring yang dilakukan lebih tinggi pada dimensi comforting care, diikuti oleh dimensi clinical care, humanistic care, dan relational care (Calong \& Soriano, 2018).

Penelitian ini menunjukkan hasil mayoritas responden berada pada usia dewasa awal yaitu 26-35 tahun sebesar $59,6 \%$. Semakin tua usia perawat maka semakin caring, karena perawat tersebut akan lebih sabar, berpengalaman dan lebih dewasa (Wahyudi, Sutria, Azhar, \& Syisnawati, 2017). Hasil penelitian 
menunjukkan sebagian besar responden memiliki masa kerja 1-5 tahun sebanyak $52,8 \%$. Perawat yang memiliki masa kerja relatif pendek (kurang dari 5 tahun), memiliki pengalaman kerja yang sedikit sehingga menampilkan kinerja yang diasumsikan kurang maksimal (Sunardi, 2014).

Mayoritas responden berjenis kelamin perempuan sebesar 64\%. Perempuan memiliki sifat kelembutan, sabar, perhatian, dan memiliki mother instinct. Perawat berjenis kelamin perempuan cenderung lebih mudah mengaplikasikan perilaku caring (Sheldon, 2010). Status pernikahan adalah menikah sebesar $91 \%$. Pernikahan menyebabkan peningkatan tanggung jawab. Perawat yang telah menikah memiliki kinerja yang lebih baik dari perawat yang belum menikah (Kumajas, Warouw, \& Bawotong, 2014). Mayoritas responden memiliki status kepegawaian non-PNS sebesar 53,9\%. Tidak ada hubungan antara status kepegawaian dengan perilaku caring perawat (Yuningsih, 2015).

Mayoritas responden memiliki jenjang karir Perawat Klinik (PK) I sebesar 55,1\%. Sistem jenjang karir akan mendorong perawat untuk meningkatkan pengetahuan dan keahliannya sehingga pengetahuan dan keahlian yang diimplementasikan akan meningkatkan caring perawat (Kornela, Hariyanto, \& Pusparahaju 2014).

Hasil penelitian pada dimensi clinical care menunjukkan bahwa responden dalam kategori baik sebesar 98,9\%. Pada dimensi ini terdapat aspek yang memiliki nilai tertinggi yaitu mengetahui cara memberikan perawatan (misal: injeksi intravena, ganti balutan, dan lain-lain). Perawat memberikan asuhan keperawatan perlu memiliki pengetahuan yang baik, sehingga akan menghasilkan caring yang baik pula. Perawat memiliki peran sebagai educator yang menjadi implementasi dari faktor tersebut. Faktor karatif pengajaran pada dimensi ini berkaitan dengan pengetahuan yang dimiliki perawat. Pengetahuan merupakan dasar dari tindakan keperawatan dan pengetahuan yang diaplikasikan akan memfasilitasi proses penyembuhan pasien (Sulisno \& Ulfah, 2012). Sebagai seorang perawat profesional, pengetahuan yang dimiliki akan mempengaruhi dalam membuat sebuah keputusan klinis yang tepat, sehingga akan berdampak pada pelayanan keperawatan yang baik (Ligita, 2012).

Hasil penelitian pada dimensi relational care menunjukkan masih terdapat 29,2\% responden dalam kategori cukup. Terdapat aspek dalam dimensi ini yang perlu ditingkatkan meliputi membantu pasien untuk melihat berbagai hal dari sudut pandang yang berbeda, membantu pasien untuk mengeksplorasi makna yang pasien berikan pada kondisi kesehatan, dan membantu pasien mengidentifikasi konsekuensi dari perilaku pasien. Aspek-aspek tersebut termasuk dalam faktor karatif pemecahan masalah. Caring perawat memberikan kesempatan kepada perawat untuk lebih mengenal dan memahami masalah kesehatan yang dihadapi pasien (Potter \& Perry, 2009). Salah satu cara membantu pasien dalam pemecahan masalah adalah dengan komunikasi terapeutik. Perawat dengan melakukan komunikasi terapeutik pada pasien, diharapkan perawat dapat mengubah cara pandang pasien tentang penyakitnya, dirinya, dan masa depannya sehingga pasien dapat menghargai dan menerima diri apa adanya (Transyah \& Toni, 2018). Hasil penelitian pada dimensi humanistic care menunjukkan masih terdapat 38,2\% responden dalam kategori cukup. Terdapat aspek dalam dimensi ini yang perlu ditingkatkan yaitu aspek perawat tidak memiliki sikap tidak setuju pada pasien dan aspek menekankan pada 
upaya perawat. Aspek tersebut termasuk dalam faktor karatif humanisme. Kurang optimalnya penerapan faktor karatif caring humanisme pada dimensi ini dapat disebabkan karena faktor kepribadian pada setiap individu. Perawat di rumah sakit memiliki kepribadian yang berbeda-beda, sehingga kualitas kepribadian setiap individu juga berbeda. Perbedaan kualitas kepribadian perawat akan mempengaruhi cara perawat dalam berinteraksi dengan pasien. Dimensi kepribadian yang mempunyai pengaruh terhadap perilaku caring perawat yaitu kepribadian extraversion, agreeableness dan kepribadian conscientiousness (Sirait, 2013).

Hasil penelitian pada dimensi comforting care menunjukkan 100\% responden dalam kategori baik. Perawat menilai kenyamanan pasien sebagai hal yang utama diberikan saat memberi asuhan keperawatan. Kenyamanan meliputi kenyamanan fisik, kebutuhan psikospiritual, kenyamanan lingkungan dan sosial (Voyles, 2010). Kenyamanan selama proses interaksi merupakan bentuk keberhasilan perawat dalam memberikan pelayanan yang baik, menciptakan lingkungan yang kondusif dan mengupayakan kesejahteraan bersama (Agritubella, 2018). Faktor karatif caring pada dimensi ini berkaitan dengan kebutuhan selama pasien mendapatkan perawatan. Pemenuhan kebutuhan pasien oleh perawat merupakan tanda bahwa perawat caring.

\section{KESIMPULAN DAN SARAN}

Dimensi clinical care dan comforting care perawat sudah termasuk kategori baik. Interaksi caring pada dimensi relational care dan humanistic care berada pada kategori cukup.

Peneliti menyarankan perawat meningkatkan komunikasi terapeutik, dan kualitas diri dengan menambah pengetahuan. Pihak rumah sakit diharapkan dapat memberikan program atau pelatihan terkait pendidikan kesehatan, komunikasi terapeutik, dan pemenuhan kenyamanan pasien.

\section{UCAPAN TERIMAKASIH}

Peneliti menyampaikan terimakasih kepada pihak rumah sakit yang telah memberikan ijin untuk melakukan penelitian. Kepada perawat yang telah bersedia menjadi responden. Semua pihak yang telah membantu peneliti dalam menyelesaikan penelitian ini.

\section{DAFTAR PUSTAKA}

Agritubella, S. M. (2018). Kenyamanan dan kepuasan pasien dalam proses interaksi pelayanan Keperawatan di RSUD Petala Bumi. Jurnal Endurcance, 3(1), 14-26. doi:10.22216/jen.v3i1.2040

Calong, K. A. C., \& Soriano, G. P. (2018). Caring behavior and patient satisfaction: Merging for satisfaction. Journal of Caring Sciences, 11(2), 697-704.

Cossette, S. Cote, J. K., Pepin, J., Ricard, N., D'Aoust, L. X. (2006). A dimensional structure of nurse-patient interactions from a caring perspective: Refinement of the Caring NursePatient Interaction Scale (CNPI-Short Scale). Journal of Advanced Nursing, 55(2), 198-214. doi:10.1111/j.13652648.2006.03895.x 
Fortuno, A. F., Oco, D. B., \& Clores, M. A. (2017). Influential components of Caring Nurse-Patient Interaction (CNPI) in a tertiary hospital in the Philippines: Towards improving health outcomes of patients. Journal of Nursing Science, 7(4), 84-90. doi:10.5923/j.nursing.20170704.02

Jannah, F., Rizani, A., \& Marwansyah, H. (2016). Gambaran perilaku caring dan faktor perilaku caring perawat terhadap pasien di ruang rawat inap RSUD Banjarbaru Tahun. Jurnal Citra Keperawatan, 5(2), 97-102.

Kornela, F., Hariyanto, T., \& Pusparahaju, A. (2014). Pengembangan model jenjang karir perawat klinis di unit rawat inap rumah sakit. Jurnal Kedokteran Brawijaya, 28(1), 59-64.

Kumajas, F. W., Warouw, H., \& Bawotong, J. (2014). Hubungan karakteristik individu dengan kinerja perawat di ruang rawat inap penyakit dalam RSUD Datoe Binangkang Kabupaten Bolaang Mongondow. Jurnal Keperawatan, 2(2), 1-8.

Ligita T. (2012). Pengetahuan, sikap dan kesiapan perawat klinisi dalam implementasi evidence-based practice. Jurnal Keperawatan, 8(1), 83-95.

Potter, P. A., \& Perry, A. G. (2009). Fundamental keperawatan (ed. 7). Jakarta: Salemba Medika.

Sheldon. (2010). Komunikasi untuk keperawatan. Jakarta: Erlangga.

Sirait, R. (2013). Pengaruh kepribadian dengan perilaku caring perawat di ruang rawat inap Rumah Sakit Umum dr. Pirngadi Medan. Universitas Sumatera Utara.
Sukesi, N. (2012). Upaya peningkatan caring perawat terhadap kepuasan pasien di ruang rawat inap RS Permata Medika Semarang. Jurnal Manajemen Keperawatan, 1, 15-24.

Sulisno, M., \& Ulfah, R. (2012). Pengetahuan perawat Tentang keperawatan holistik. Journal Nursing Studies, 1, 157-162.

Sunardi. (2014). Analisis perilaku caring perawat pelaksana. Jurnal Keperawatan, 5(1), 69-78.

Tiara, \& Lestari, A. (2013). Perilaku caring perawat dalam meningkatkan kepuasan pasien rawat inap. Jurnal Keperawatan, 9(2), 115-120.

Transyah, C. H., \& Toni, J. (2018). Hubungan penerapan komunikasi terapeutik perawat dengan pasien. Jurnal Endurance, 3(1), 88-95. doi:10.22216/jen.v3i1.2487

Voyles, E. (2010). The art of comfort care. Journal of Nursing, 25(2), 11. doi:10.1016/j.pedn.2009.12.034

Wahyudi, Sutria, E., Azhar, M. U., \& Syisnawati (2017). Faktor-faktor yang berhubungan dengan perilaku caring perawat di ruang perawatan interna. Journal of Islamic Nursing, 2(2), 8292.

Yuningsih, D. Y. A. (2015). Hubungan status kepegawaian perawat dengan perilaku caring perawat pada pasien di Ruang RSD Balung. Universitas Jember. 